\title{
CONTROVERSIAL EXPERIENCE TOURISM IN THE EYES OF GENERATION Y REPRESENTATIVES
}

\author{
MAGDALENA DOLIŃSKA ${ }^{1}$, LESZEK S. DĄBROWSKI ${ }^{2}$, \\ ELŻBIETA GRZELAK-KOSTULSKA ${ }^{3}$
}

\author{
Nicolaus Copernicus University in Torun \\ Faculty of Earth Sciences \\ 1 e-mail: 276321@stud.umk.pl \\ 2 e-mail: 275468@stud.umk.pl \\ 3 e-mail: grzelak@umk.pl
}

\section{JEL CODES \\ KEYWORDS}

ABSTRACT
Z32, L83, L10

controversial tourism, controversial experience tourism, Generation Y, experience economy

This paper was written to contribute to the discussion on the perspectives of the development of selected forms of controversial tourism by means of: 1) surveying opinions of Generation $\mathrm{Y}$ representatives on how familiar they are with individual forms; 2) determining the responders' impressions on acceptance of these forms; 3) gathering opinions on the perspectives of development of these forms. The starting point for the discussion is to approach the motives for such travels from the perspective of the concept of experience economy and to limit the research to tourism forms developing in response to the need of novelty, sensations and experiences. The demand factor connected with the need to maximize sensations shaped a specific form of tourism, described in this study as controversial experience tourism. It comprises sex tourism, drug tourism, disaster tourism, extreme tourism, thanatourism, esoteric tourism, urban exploring and poorism.

The study was carried out with the help of the CAWI technique between February and May 2018 and involved 407 participants aged 18-26.

The obtained results suggest relatively low future interest in forms of tourism that are perceived as strongly controversial. The thirst for new experiences and sensations is fully satisfied by these forms of extreme tourism that are positively perceived and do not arouse ethical controversies.

\section{Introduction}

Observation and participation are the main elements of experiencing. Due to them, every day people develop, achieve successes and pursue their passions; they also learn and change the way they think and perceive the world. New experiences are also the primary factor motivating people to travel as tourists. Everybody has their own reasons to choose a particular destination, from relaxing on a beach to unwinding by intense sightseeing and physical activity. In both cases, sensory 
perceptions and accompanying emotions are of key importance (Andersson, 2007; Niezgoda, 2013). In time, however, the need to intensify them may take less than desirable directions: the emerging forms of tourism may be increasingly questionable.

In 2015 Polish literature was enriched by an interesting article by Andrzej Stasiak, containing an overview of the issue of controversial tourism practices. In the last sentence, the author posed a very significant question regarding future of such tourism, which certainly has become an inspiration for further research on this topic, including this analysis.

The term "controversial tourism", as Stasiak emphasizes, can be very broadly understood and may refer to a variety of problematic travel forms (Stasiak, 2015) which are debatable or cannot be judged unambiguously. They are abundantly described in literature, as it can be seen from a growing number of publications (Puchnarewicz, 2009; Borzyszkowski, 2011; Komsta, 2013; Jędrysiak, Kamel, 2014; Niezgoda, Duczyńska, 2014; Poczta, Szebiotko, 2014; Stasiak, 2015; Gandecka, 2016; Motyka, 2016; Pokojska, Suszczewicz, 2016). According to some researchers, such as LubowieckiVikuk and Paczyńska-Jędrycka (2010), this term is limited only to abortion tourism, euthanasia tourism and drug tourism. The gist of controversial tourism is explained most fully by Aleksander Panasiuk (2018): he writes about controversial areas of the tourist market, analysing them from the perspective of the structure of this market. Systematising current knowledge, he analyses the controversies regarding demand and supply in tourism as well as socioeconomic policy, in particular tourism-related policy.

As Panasiuk (2018) demonstrates, controversies can be more broadly interpreted, depending on the adopted perspective; however, it is unclear to what degree the presence of dysfunctions justifies including a given form in the sphere of controversial tourism (e.g. a conflict of the spatial type, emerging due to pressure caused by large influx of tourists whose presence disturbs everyday functioning of a settlement, especially a historical city (Kowalczyk-Anioł, Zmyślony, 2017).

The starting point in the discussion on the development of controversial tourism are the following theses:

1. Perceiving tourists' motives from the perspective of the concept of experience economy (Andersson, 2007; Nowacki, 2009; Żemła, 2017) seems to be fully justified and adequate with regard to new trends in tourism described in literature. According to the research, modern tourists with increasing frequency seek their own paths and authenticity; above all, they become, as Zygmunt Bauman writes, the collectors of impressions: they collect objects only secondarily, as derivatives of experiences (Bauman, 2000). As individuals in a modernized society, they strive to satisfy individual needs, including the need to manifest their own distinctiveness by gathering a growing number of experiences of increasing intensity and originality. It should be emphasized that

a tourist product can be freely interpreted by the consumers, in their individual, unique way, because their own sensations, experiences and memories become the fundamental value purchased by the tourists-consumers. It is they who decide which elements of the product are most important and which of the many options to select will best satisfy [their] needs (Niezgoda, 2013, p. 46). 
The co-existing need to maximize experiences (Niezgoda, 2013), as rightly noted by Stasiak (2015) and Iwasiński (2015), can lead to search for stronger and stronger stimuli and consequently to trying activities that are controversial.

2. To continue the issue of controversies connected with demand, where tourists' motives become the key identifier, only some of the mentioned forms can be reduced to a common denominator. The perspective adopted in this analysis consciously limits the range of issues to the forms that have emerged in response to thirst for novelty, sensations and experiences. It seems that distinguishing a certain set of controversial tourism variations by applying such a criterion is fully justified, as the study results can then be explained - it is difficult to address unambiguously the economic or ecological controversies characteristic for mass tourism, or the moral-ethical and aesthetical controversies related to forms focusing on the need for strong sensations. Motives that underlie trying such distinct tourism forms are entirely different, as in case of abortion or euthanasia tourism, where tourists' experiences are not an appropriate point of reference. The demand factor related to the need to maximize sensations has shaped a specific group of tourism forms, described in this analysis as controversial experience tourism. Its scope includes sex tourism, drug tourism (one must be aware that trips connected with pathological behavior resulting from such nosological units as drug or sex addiction should be located outside the set), disaster tourism, extreme tourism, thanatourism, esoteric tourism, urban exploring and poorism.

Besides the need to draw attention to the above-described methodological aspect (a coherent motive as a condition of effective explanation), the aim of this study is to contribute to the discussion on the development perspectives of selected forms of controversial tourism. Defining developing trends is a very difficult task, bearing a risk of error; however, some grounds for drawing conclusions can be provided by opinions gathered among young people (representatives of Generation Y), who will be setting the main directions of demand in tourism. The analysis was planned to start with estimating the degree of recognizability of specific forms, followed by impressions regarding acceptance of these forms and ending with opinions on the perspectives of their development.

\section{Material and methods}

To collect responders' opinions on selected forms of controversial tourism, the authors used the CAWI (Computer Assisted Web Interviews) technique. The poll was carried out once, between February and May 2018, with full anonymity of the responders preserved (Szyjewski, Szyjewski, 2017). The number of participants was 407 (including 240 women) aged 18-26.

The questionnaire was constructed in a classical way, mostly using closed questions as well as a dychotomic scale, a nominal scale and a modified version of Likert scale. The proper study was preceded by a pilot test, which in one case revealed the need to rework the nominal scale. Part of the questions was used to determine the responders' features: not only their general socio-demographic characteristics but also how active they had been as tourists, based on the frequency and range of their previous travels. The subsequent questions constituted a sequence, where the first step 
involved determining responders' knowledge of particular controversial tourism types. This was followed by brief definitions of particular types (as a mini-dictionary) so that people unfamiliar with a given form could learn about it and formulate their own opinion. The next and most crucial part contained specific questions regarding problems and consequences related to practicing different controversial forms of tourism.

Using a scheme of non-probability sampling, it was decided that the responders would be selected based on their availability. The number of questionnaire interviews depended on the availability responders, who were notified by mail about the research poll.

After questionnaire verification (two were discarded at that point), 405 of them were used to build a database with the IBM SPSS software; its contents were subjected to further statistical analysis. The tested sample cannot be considered statistically representative; however, it seems that the somehow significant number of collected opinions makes it possible to draw careful conclusions and make generalizations.

\section{Results}

According to the adopted research scheme, the first group of questions was to determine the level of responders' knowledge regarding the specified forms of tourism. The responders picked extreme tourism as the most frequently identified one (59\%), followed by sex tourism (40\%) and urban exploring (36\%). A third of the responders heard about drug tourism and disaster tourism. The least known form is poorism, selected only by $12 \%$ of the responders.

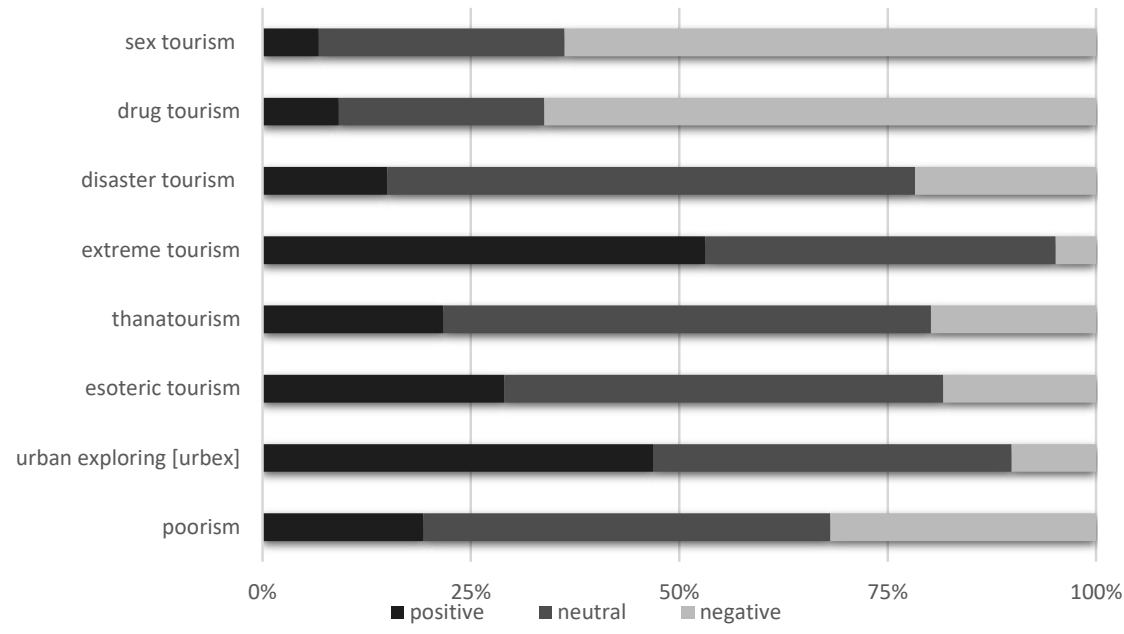

Figure 1. Ethical evaluation of selected tourism forms

Source: authors' own questionnaire-based research $(\mathrm{N}=405)$.

Among the most recognizable forms, two create positive impressions (80-90\% of choices): extreme tourism and urban exploring. Slightly more than half of the responders have such associations 
with esoteric tourism and thanatourism. Quite well recognized sex tourism and drug tourism are perceived negatively by almost $90 \%$ of the responders. The majority of controversial tourism types is judged to be ethically neutral (disaster tourism, thanatourism, esoteric tourism). Drug tourism and sex tourism are most frequently described as unethical, as it was pointed out by $28 \%$ and $24 \%$ of the responders respectively, while few responders perceive poorism, disaster tourism and thanatourism in these categories. This matches the evaluation of ethicality of the selected tourism forms, although a significant part of the responders - particularly in the case of forms that do not evoke unambiguous associations - suggests that they are of neutral character (fig. 1).

A key element of the diagnosis was to determine how interested the responders were in practicing the selected tourism forms. The responders most frequently stated that they had not tried any of the mentioned forms of tourism nor are they going to try them in the future (fig. 2), which does not suggest any need to experiment in this sphere.

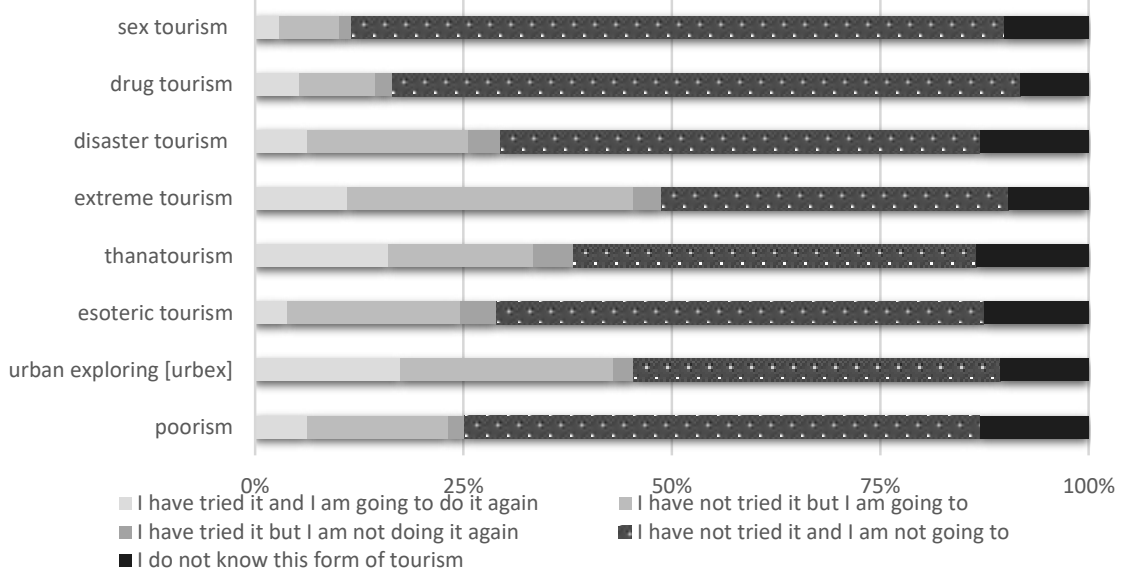

Figule 2. Interest in practicing the specific forms of tourism

Source: authors' own questionnaire-based research $(\mathrm{N}=405)$.

An exception is extreme tourism: although only less than $20 \%$ of the responders had tried it, almost $40 \%$ would like to do so in the future. Similar opinions were also expressed about urban exploring, followed by thanatourism, disaster tourism and esoteric tourism. The responders were most interested in forms with positive associations, which are thought to have educational and cognitive value and whose potential controversies are overlooked.

The next step of the study involved an attempt to discover responders' impression on the development potential of each analyzed form of tourism (fig. 3). 


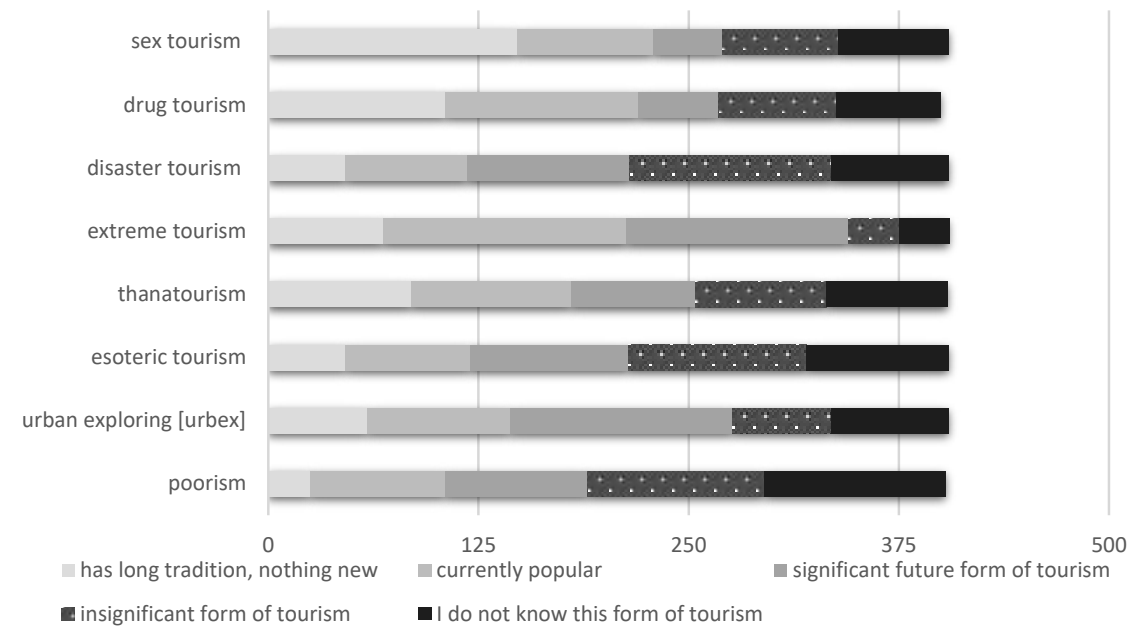

Figure 3. Development potential of selected tourism forms

Source: authors' own questionnaire-based research $(\mathrm{N}=405)$.

Sex tourism and drug tourism are quite frequently mentioned as forms with long traditions that do not offer anything new. Drug tourism and extreme tourism are considered to be currently popular, but according to the responders only the latter form has future perspectives. Urban exploring and thanatourism are viewed similarly by the responders; however, the latter is considered to be a niche form.

\section{Discussion}

Tourism is a dynamic phenomenon, subject to constant changes in response to consumers' demands, aims and requirements, which in turn are shaped e.g. by social trends, which are of key importance in the case of the so-called controversial tourism. As Dahrendorf (1990) argued, in postindustrial societies life focuses around services. According to his concept of service society, the structure of production and employment is shifting from traditional production industry to the sector of broadly understood services. Besides, formal education and professional experience create a potential for independent decision-making (Bell, 1973; Bell, 1974; Inglehart, 2005). Thus emergence of post-industrial society leads to growing emphasis on self-expression (Inglehart, 1997). Furthermore, economic security of developed societies is guaranteed in the conditions of a welfare state. This leads to changing priorities in the system of values, which shift from economic and physical security to increasing importance attached to subjective well-being and quality of life (Inglehart, 1977, 1997, 2005).

Among many approaches applied to interpret contemporary changes, several of them are noteworthy as potential starting points in a discussion on the directions in development of controversial experience tourism. In reference to generational differences, Inglehart's concept explaining 
reasons for changes that occur in developed societies (Inglehart, 2005) should be mentioned. In his opinion, the first generation that has grown among prosperity, in comparison with the previous generation, changes the hierarchy of values in the society, as the attention of individuals turns to satisfying higher-level needs, such as the need to belong and respect, which may be a significant motivator when these people make decisions about travelling. It should be stressed that the hierarchy of values does not adapt to the socioeconomic environment immediately; there is a significant delay, as fundamental values of a particular person to a great extent reflect the conditions from the time before such a person has reached maturity (Inglehart, 2005). Thus the generation of parents remains attached to materialist values. Experiencing stability and economic security on the scale of an entire society leads to decreased importance of material goods and increased significance of post-material goods. In this context, the conclusions to be discussed are basically reduced to confirmation of experiences gathered during travels; however, it may be worth wondering whether they will deepen in the form of simple emotions, or whether further evolution towards post-materialistic values will bring the need to achieve deeper sensations on significantly more intellectual foundation. The responders point out that they are interested mostly in forms which have the character of educational trips, and any controversies are related mostly to the matters of security (although urban exploring may also raise legal doubts).

Concerning the character of this study, one should also look at the results from the generational perspective. Analyses of tourist demand with increasing frequency emphasize relations between consumers who are linked by similar generational experiences (see Dąbrowski, Kwiatkowski, Lepa, Środa-Murawska, Grzelak-Kostulska, 2016). The studied group belongs to Generation Y and - although the literature is filled with an ongoing debate on the age limits of this generation - all researchers agree that it is the largest segment of the world market (Heaney, 2007; Foscht, Schloffer, Maloles, Chia, 2009; Gołąb-Andrzejak, 2016). It is assumed that the main features of this generation are: good education and willingness to pursue personal development; being active; widespread use of new technologies; appreciation of quality of life and life experiences instead of property ownership; openness; belief in one's own uniqueness. This generation "appreciates the power of image, of self-invention; they focus on building their own image. In comparison with the previous generation, they need more acceptance from their peers, frequently connecting with the latter through social media" (Zajadacz, 2014, p. 60). Generation Y members constantly expect novelties on the market; when buying products and services, they are inclined to experiment in search of new sensations as well as of internal peace and deeper, more conscious life (Cohen, 2009; Zajadacz, 2014). The mentioned features do not allow an unerring prediction of features that this group of service purchasers has because, on the one hand, the ease of travelling and the need to collect new experiences and gain fame among their acquaintances (mostly in social media) can encourage people to undertake even strongly controversial trips, and on the other hand, easy access to information and better education may limit their selection, particularly by removing options involving most radical and dangerous tourism form. The analyzed study results arise a certain skepticism, as the group of responders who declare their willingness to experiment and try new things has turned out to be rather limited. 
Seeking increasingly stronger sensations and emotions in tourism - despite consequences that take the form of different costs - sometimes turns out to be a trap. It may be worth recalling the thesis of a British sociologist Anthony Giddens that modernity contains in itself a self-correction mechanism, so the observed changes are nothing but an attempt to stop its negative consequences. This is possible because the society has developed a new competence: self-reflectivity. Giddens (2009) understands this as the society's ability to perceive the reality critically so that it is able to take preventive or corrective measures.

Finally, one more concept should be mentioned, which fits the model of cyclical development, according to which the "rush into future must turn back towards the past". As Ronald Inglehart writes, it may not be excluded that a nostalgic idea of return to the lost past will appear in answer to modernity: a hope for rebuilding the traditional, strong family, rebirth of local communities and social bonds in primary groups, turn from secularization towards religion etc. (Inglehart, 2005). This trend seems to be gaining significance and is visible in the increase of conservative attitudes in numerous countries. It is, however, debatable whether the society will return also to traditional consumer behavior. If yes, then the frequently stated thesis regarding the need for continuous escalation of experiences may turn out to be wrong. The results of the presented research seem to confirm this because tourism forms arousing moral and ethical controversies have received a clearly negative assessment.

Certain social trends connected with demographic changes should also be taken into account. The aging society is perceived as increasingly conservative and resistant to change, careful in spending due to their need for safety (despite the presence of intergenerational exchange that modifies the attitudes of older people) (Grzelak-Kostulska, 2016). These determinants - though not related directly to the character of the responders' group - should also be included in the discussion of directions in development of controversial tourism.

\section{Conclusions}

As foreseen, the results of research carried out among representatives of Generation Y may constitute a basis for conclusions regarding the future of the experience tourism forms that arise certain controversies. The responders declare relatively low level of knowledge of the forms included in the study (only extreme tourism has been recognized by more than half of the group), which can evidence low interest in this kind of travelling.

Most popular forms are those considered as not very controversial, such as urban exploring, extreme tourism and thanatourism (associated rather with travelling to places of historical importance). Urban exploring and disaster tourism are mentioned as forms that may gain importance in the future. The forms rated worst - sex tourism and drug tourism - are not perceived as promising. It should be noted, however, that the responders consider drug tourism to be popular, declaring at the same time that they have never tried it, nor are they going to try it in the future.

Together with the discussion on attitudes, models of behavior and social trends, the obtained results suggest relatively low future interest in forms of tourism associated with strong controversies. 
Perhaps ethics plays here a certain role, discouraging from undertaking trips that have received a clearly negative assessment. The need to gather new experiences and sensations is fully satisfied by forms of extreme tourism or urbex (urban exploration), which are not associated with controversial phenomena (although tourists' safety may be debatable); they both provide the desired emotions and underline the uniqueness and individualism of a person practicing such a form, without exposing them to negative judgment of other people. Thus in the eyes of the responders the future of experience tourism seems to follow a direction far from any ethical controversies.

\section{References}

Andersson, T. (2007). The tourist in the experience economy. Scandinavian Journal of Hospitality and Tourism, 1 (7), 46-58.

Bauman, Z. (2000). Globalizacja. I co z tego dla ludzi wynika? Warsaw: Państwowy Instytut Wydawniczy.

Bell, D. (1973). The coming of Post-Industrial Society. A Venture in Social Forecasting. New York: Penguin Books.

Bell, D. (1974). The coming of the Post-Industrial Society. London: Heinemann.

Borzyszkowski, J. (2011). Problem zdefiniowania i klasyfikacji seksturystyki. Turystyka kulturowa, 1, 19-31.

Cohen, A. M. (2009). The Emergence of a Global Generation. The Futurist, 1 (43), 57-59.

Dahrendorf, R. (1990). The Modern Social Conflict. Berkeley: The University of California Press.

Dąbrowski, L., Kwiatkowski, M., Lepa, M., Środa-Murawska, S., Grzelak-Kostulska, E. (2016). Aktywność turystyczna generacji Z. In: W. Błaszczuk, A. Ziemski (eds.), Turystyka akademicka 1906-2016. 60 lat BPiT Almatur 1956-2016 (pp. 307-319). Warsaw: Kto jest Kim.

Foscht, T., Schloffer, J., Maloles, C., Chia, S.L. (2009). Assessing the outcomes of Generation-Y customers' loyalty. International Journal of Bank Marketing, 3 (27), 218-241.

Gandecka, A. (2016). Ostatnia enklawa autentyczności? Slumsy jako atrakcja turystyczna. Turystyka kulturowa, 6, 90-107.

Giddens, A. (2009). Europa w epoce globalnej. Warsaw: Wydawnictwo Naukowe PWN.

Gołąb-Andrzejak, E. (2016). Konsumenci pokolenia Y - nowe wyzwanie dla komunikacji marketingowej. Handel Wewnętrzny, 2 (361), 140-151.

Grzelak-Kostulska, E. (2016). Seniorzy w Polsce w świetle procesów modernizacyjnych. Toruń: Wydawnictwo Naukowe Uniwersytetu Mikołaja Kopernika.

Heaney, J.G. (2007). Generations X and Y's Internet Banking Usage in Australia. Journal of Financial Services Marketing, 3 (11), 196-210.

Inglehart, R. (1997). Modernization and postmodernization: cultural, economic and political change in forty three societies. Princeton: Princeton University Press.

Inglehart, R. (2005). Pojawienie się wartości postmaterialistycznych. In: P. Sztompka, M. Kucia (eds.), Socjologia. Lektury (pp. 334-348). Cracow: Znak.

Inglehart, R. (1977). The Silent Revolution: Changing Values and Political Styles Among Western Publics. Princeton: Princeton University Press.

Iwasiński, Ł. (2015). Turystyka jako rynek doświadczeń. Kultura popularna, 2 (44), 28-38.

Jędrysiak, T., Kamel, M. (2014). Turystyka ezoteryczna - zjawisk paranormalnych. Turystyka kulturowa, 7, 20-33.

Komsta, A. (2013). Problemy dark tourism i jego możliwości w Polsce. Turystyka kulturowa, 2, 46-65.

Kowalczyk-Anioł, J., Zmyślony, P. (2017). Turystyka miejska jako źródło protestów społecznych: przykłady Wenecji i Barcelony. Turystyka kulturowa, 2, 7-36.

Lubowiecki-Vikuk, A., Paczyńska-Jędrycka, M. (2010). Współczesne tendencje w rozwoju form rekreacyjnych i turystycznych. Poznań: Bogucki Wydawnictwo Naukowe.

Motyka, M. (2016). Turystyka narkotykowa. Hygeia Public Health, 1 (51), 31-38. 
Niezgoda, A. (2013). Turystyka doświadczeń - dawna czy nowa forma turystyki?. Warsztaty z Geografii Turyzmu, 3 (pp. 37-47).

Niezgoda, A., Duczyńska M. (2014). Seksturystyka jako przykład popytu szkodliwego w turystyce. VI Ogólnopolska Konferencja Naukowa „Turystyka w humanistycznej perspektywie. Etyczny wymiar podróży kulturowych”, 25-26 września 2014 (pp. 158-167). Poznań: Akademia Wychowania Fizycznego w Poznaniu.

Nowacki, M. (2009). Aktualne tendencje na rynku atrakcji dla odwiedzających. In: A. Stasiak (ed.), Kultura i turystyka razem, ale jak? (pp. 267-284). Łódź: Wydawnictwo WSTH w Łodzi.

Panasiuk, A. (2018). Kontrowersyjne obszary rynku turystycznego. Ekonomiczne Problemy Turystyki, 2 (42), 37-47.

Poczta, J., Szebiotko, I. (2014). Seksturystyka - między turystyką kulturową a patologiczną. Turystyka kulturowa, 4, $16-27$.

Pokojska, W., Suszczewicz, M. (2016). Turystyka miejsc niechcianych - poradzieckie garnizony w Polsce Zachodniej. Turystyka kulturowa, 2, 101-115.

Puchnarewicz, E. (2009). „Turystyka islamska” jako nowa koncepcja rozwoju turystyki w świecie muzułmańskim. Zeszyty Naukowe Turystyka i Rekreacja, 2 (4), 51-68.

Stasiak, A. (2015). Turystyka kontrowersyjna jako emanacja gospodarki doświadczeń. In: G. Godlewski, M. Zalech (eds.), Turystyka kontrowersyjna na wspótczesnym rynku podróży - formy, uwarunkowania, skutki (pp. 53-69). Biała Podlaska: Akademia Wychowania Fizycznego Józefa Piłsudskiego w Warszawie, Filia w Białej Podlaskiej.

Szyjewski, Z., Szyjewski, G. (2017). Wiarygodność metod badawczych. Informatyka Ekonomiczna, 2 (44), 118-131.

Zajadacz, A. (2014). Pokolenie X, Y, Z a fenomen turystyki. In: J. Śledzińska, B. Włodarczyk (eds.), Międzypokoleniowe aspekty turystyki (pp. 55-67). Warsaw: PTTK.

Żemła, M. (2017). Rola koncepcji ekonomii doświadczeń w postmodernistycznej interpretacji trendów rynkowych w turystyce i budowie nowoczesnych produktów turystycznych. Prace Komisji Geografii Przemystu Polskiego Towarzystwa Geograficznego, 3 (31), 7-16.

\section{KONTROWERSYJNA TURYSTYKA WRAŻEŃ W OPINII PRZEDSTAWICIELI POKOLENIA Y}

SŁOWA KLUCZOWE STRESZCZENIE turystyka kontrowersyjna, kontrowersyjna turystyka wrażeń, pokolenie Y, ekonomia doświadczeń

Celem pracy jest włączenie się w dyskusję nad perspektywami rozwoju wybranych form turystyki kontrowersyjnej poprzez: 1) zbadanie opinii przedstawicieli pokolenia $Y$ na temat oceny stopnia znajomości poszczególnych form, 2) określenie odczuć respondentów na temat ich akceptacji, 3) zebranie opinii na temat perspektyw rozwojowych wskazanych form. Punktem wyjścia do dyskusji jest spojrzenie na motywy podejmowanych podróży z perspektywy koncepcji tzw. ekonomii doświadczeń oraz ograniczenie zakresu problemowego do form turystyki rozwijających się pod wpływem potrzeby poszukiwania nowości, wrażeń, doświadczeń. Czynnik popytu związany z potrzebą maksymalizacji wrażeń ukształtował pewną specyficzną grupę form turystyki, określoną na potrzeby analizy jako kontrowersyjna turystyka wrażeń. W jej zakres włączono: turystykę seksualną, narkoturystykę, turystykę katastrof, ekstremalną, tanatoturystykę, turystykę ezoteryczną, urban exploring i poorism.

Badanie wykonano z zastosowaniem techniki CAWI, w okresie od lutego do maja 2018 roku z udziałem 407 respondentów w przedziale wiekowym 18-26 lat.

Uzyskane wyniki sugerują stosunkowo niewielkie zainteresowanie w przyszłości formami turystyki, które kojarzone są jako silnie kontrowersyjne. Potrzebę zdobywania nowych doświadczeń i wrażeń w pełni zapewniają formy turystyki ekstremalnej, które postrzegane są pozytywnie i nie wywołują kontrowersji natury etycznej. 